\title{
Deep rooted conflicts and Industrial Relations interface in Botswana
}

\author{
Baakile Motshegwa (Corresponding Author) \\ University of Botswana, Department of political and Administrative Studies \\ Private Bag UB00705, Gaborone, Botswana \\ Tel: +267 3552352 Fax: +2673170706 Email: Motshegwa@mopipi.ub.bw \\ Theophilus Tebetso Tshukudu \\ University of Botswana, Department of political and Administrative Studies \\ Private Bag UB00705, Gaborone, Botswana \\ Tel: +267 $3554169 \quad$ Email: Theophilus.Tshukudu@ mopipi.ub.bw
}

Received: August 28, 2012 Accepted: September 10, 2012 DOI: 10.5296/jpag.v2i3.2349

\begin{abstract}
Conflict is inherently part of any industrial relations environment. With the advent of employee - management relations, conflict is bound to be and has always been present. This paper looks at conflict as it occurs in an organisation between employees and management and also government. Botswana has of recent witnessed a series of industrial relations conflict that can be categorised into three areas; union to union conflict; and union management conflict and union - government conflict. Desktop methodology was used to collect information for this paper and some of the major events that have occurred in the Botswana industrial relations are referred to in this paper.
\end{abstract}

Keywords: Trade unions, industrial relations, Botswana, conflict, strike 


\section{Introduction}

The advent of trade unionism in Botswana dates back to colonial era when there were very few educated Batswana who understood the purpose of unions. At the outset, trade unions were started mainly by political activists who were also the pioneers of early political parties in Botswana (Mogalakwe M. , 1997). Employers on the other hand had few workers whom they controlled with an iron fist and who did not have many choices when it came to alternative jobs. Conflict is inherently forms part of trade unionism. This conflict may manifest in several forms; internal conflict (conflict between and within unions themselves) and external conflict (between unions and government or management). This paper generally discusses conflict that has arisen in Botswana unions in recent years.

\section{Definitions}

The term industrial relations is sometimes used interchangeably with labour relations. By definition industrial relations is "aassociated with industrial trade unions, collective bargaining and strikes" (Bratton and Gold 2003:258). According to Salamon (2000:5) industrial relations is "concerned with male, full-time unionized, manual workers in large manufacturing units involving restrictive practices, strikes and collective bargaining". Naukrihub.com views industrial relations as being comprised of two terms: 'Industry' and 'Relations'. "Industry" refers to "any productive activity in which an individual (or a group of individuals) is (are) engaged". By "relations" we mean "the relationships that exist within the industry between the employer and his workmen." http://industrialrelations.naukrihub.com/introduction.html. Labour relations according to (Holley, 2009, p. 6) "involves managers (representing the ownership interests) and a labour organisation agent representing the interest of a group of employees engaged in the joint determination and administration of the work rules".

\section{Research methodology}

Secondary data was collected when compiling this paper. The advantage of this methodology is that data is readily available for the researcher. It also faster to collect secondary data and the cost is minimal in terms of money and time (Zikmund et al., 2013, Tharenou et al. 2007, Quinlain, 2011). The advent of the internet has even made data collection much faster than when it was done manually. The data was collected from government documents, internet sources, journals, policy documents, formal memos and books. The disadvantages are that the data may not have been specifically designed for the researcher needs. Sometimes the information may be inadequate for the researcher and researchers need to be careful when using this type of data (Zikmund et al., 2013). Gaining access to the information could also pose a challenge (Tharenou et al. 2007)

\section{Relevant statutes in Botswana on industrial relations issues}

Several statues set out the platform for industrial relations in Botswana. These will be briefly discussed in this section. Among these are: Trade Unions and Employers Organisation 
Act; Trade Disputes Act (2003), Public Service Act (2008); Employment Act (2003) and Workmen's Compensation Act. It is important to discuss such laws and the next section deals with that.

\section{a. Employment Act Chapter 47:03}

The Employment Act (EA) Chapter 47:01 provides among other things for contract of employment for public servants. Some of the items covered under contract of employment include oral or written contracts of employment, termination of contract of employment, breaches of contract of employment, certificate of employment, redundancy, termination of employment, severance benefits on termination of employment, and others. The EA further stipulates recruitment matters, issues of forced labor, protection of wages, rest periods, hours of work holidays and other conditions of work, employment of children and young persons, employment of infirm and handicapped, labor health areas, determination of minimum wages and other. The Employment (Amendment) Act, 2003 added the dimension of establishing the Labor Advisory Board which will

(a) advice the Minister on any proposed legislation rules, codes, guidelines and model agreement relating to disputes prevention and resolution;

(b) review disputes prevention and resolution procedures under the Trade and Disputes Act and advice the Minister thereon where necessary;

(c) advice the Minister on the qualifications, appointments, terms and conditions of employment, and the removal of mediators and arbitrators appointed in terms of section 4 of the Trade Disputes Act and

(d) advice the Minister in respect of any matter on which advice or recommendations are required or permitted in terms of this Act or any other labor law (Employment (Amendment) Act, 2003: A50).

\section{b. Public Service Act}

The Public Service Act (PSA) has been amended several times the most recent amendment was in 2008 and was launched on the $1^{\text {st }}$ May 2008 by the Directorate of Public Service Management. The PSA No 30 of 2008 merged the three Acts that used to operate simultaneously in the country; that is the Public service Act which was for central government employees, the Teaching Service Act for teachers and the Local Government Service Act for local government employees. The PSA stipulates several issues pertaining to the administration of the public service, appointments to the public service which included appointments probation and promotion, termination of appointments and retirements, duties of public service officers, misconduct and unsatisfactory service, offences and penalties and others.

\section{c. Trade Unions and Employers Organization Act (TUEA) Chapter 48:01}


The TUEA lays down the roles of the Registrar of Trade Unions and Employer organizations, the registration of Trade unions, federations of trade unions and employer organizations and all the procedures that are followed when registering these unions and organizations. It also spells out the rights and liabilities of trade unions, federations of trade unions and employer organizations. Furthermore, it covers membership, officers, employees and trustees and other issues like constitution and notification of other matters, finance, recognition of registered trade unions as negotiating bodies and others.

\section{d. Trade Disputes Act No 15 of 2004}

The Trade Disputes Act of 2003 (TDA) cover issues ranging from the establishment of panel of mediators and arbitrators, procedures for settlement of trade disputes generally, provides for the industrial court, settlement of claims that recognized terms and conditions of employment are not being observed, deals with issues of collective labour agreements and unlawful industrial action and enforcement of collective labour agreement and decisions of the industrial court.

\section{e. Workmen's Compensation Act Chapter 47:03}

The Workmen's Compensation Act was enacted to safeguard employees and seek compensation for them when they are injured at work. Specifically, it covers issues of eligibility for compensation, compensations for injury, medical aid, occupational diseases, compulsory insurance administration of the act, Commissioner for workmen's compensations and general issues like remedies against employer and strangers, regulations, offences and others.

\section{Intra and inter-union relations and conflicts in the Botswana Union Movement}

The trade union movement in Botswana had suffered from crippling, internal feuds. Such feuds have served to stifle their growth as institutions, policy advocates and general social activists. These feuds have left them rather fragmented and unable to organize and win major concessions with employers; DEBSWANA, for example, in the years 2004/2005, could dismiss workers who engaged in strikes with little repercussions. Furthermore, through these fragmentations, the unions have missed an opportunity to act in solidarity and have any meaningful political influence. The lack of political influence is in part a result of failure to organize and have huge memberships as politics itself is a 'game of numbers'. Trade unions need to develop strategies through which the trade union movement can become a robust block needed by government in passing various legislation and policies.

For a country with a population of just about 2 million people, and about 298,900 formally employed people according to Friedrich Ebert Foundation, (Frderick Ebert Stiftung, 2006) it appears that 25 active trade unions is a huge number. The duplication of such is often not necessitated by deep seated organizational or other differences, but by differences over simple operational issues. In 1988 for example, The BFTU's two largest affiliates - the National Amalgamated Local and Central Government and Parastatal Manual Workers Union 
(BMWU) and the Commercial and General Workers Union of Botswana (CGWU) - broke away because they wanted the independence to decide which political party to support (Dlamini, 2002). Tregenna (2005) also argues that the Botswana Federation of Trade Unions (BFTU) was formed in 1977 with governmental "assistance", and government historically had an ex officio seat in all union meetings. Issues of the BFTU's political affiliation led to a split in the federation in 1988 with affiliates wanting political independence breaking away. The affiliates were to later on return to the BFTU fold, though after an agreement to let members support whichever political party they so choose to. This buttresses the point that any such differences were not too huge to reconcile. The unions could have in the first place reached a consensus and avoided the split.

The split was a debilitating blow as Dlamini (2002, p. 20) points that

This dealt a severe blow to the BFTU whose membership was reduced by more than half due to the split. The main reasons for the breakaway were disagreements on whether BFTU affiliates should be aligned to political parties or should they be neutral and only have political affiliation on an individual basis.

Such differences would normally be to the delight of most employers and even the ruling party. In Botswana, this seemed evident as the ruling BDP under whose government the BFTU was formed, was implicated as one of those fueling dissent in the perceived opposition parties who were sympathetic to the union movement.

The latest problems within the trade union movement surfaced in 2008 when the Botswana Public Employees Union (BOPEU) and the National Amalgamated Local and Central Government Manual and General Workers Union (NALCGMGWU), were amalgamated and registered by the Registrar of Trade Unions and Employers' Organizations in the Ministry of Labour and Home Affairs as Botswana Federation of Public Sector Unions (BOFEPUSU). The amalgamation was a bid by public sector unions to bargain better with their employer. This carries serious implications for the BFTU which currently includes both private sector and public service Unions. Hitherto, the BFTU has been the single umbrella body for unions in Botswana but as the name of the new union suggests, it is viewed to be an all embracing public sector union, whilst in fact there are other public services unions outside the fold of the new federation.

This duplication is also to counter the efforts of the BFTU and its affiliates to trim down the number of unions in Botswana. As such, it presents a challenge as to who really represents workers. Naturally, the already existing Federation felt somewhat threatened by the new formation and so are the ideals of unions' consolidation. Despite these challenges, the trade union movement has recognized that it needs to trim down its numbers. This has led to the restructuring of BFTU from 25 to 13 unions.

Dlamini (2002) also believes such restructuring and consolidation will be of great help to the labour union movement as the amalgamation process will facilitate the merger of allied trade unions within the same sector in order for them to have one voice and to be able to bargain by 
sector. In a country where union membership is quite low, such consolidation would help ensure the voice and impact of labor discontent is felt. This was greatly helped by some relaxation in the labor laws of the country, with the public servants allowed to unionize since 2003/2004 with the transformation of public sector associations into unions. This move has been welcome by the Friedrich Ebert Stiftung (Frderick Ebert Stiftung , 2006) as they argue that the transformation of public sector associations (e.g. for the teachers) into unions will enhance the political weight of the labour movement in Botswana. The transformation would give unions a voice in government, allow them to bargain and negotiate the terms and conditions of service with their employer(s). According to Dzimbiri (2006) trade unions have five distinctive roles: unions provides countervailing power to the employer and a pressure group within society economic regulation through maximising the wages and employment of their members within the framework of the wage /work contract of employment, job regulation through creating a joint rule making system to prevent arbitrary management actions. Unions also play a social change role as they can influence the social cohesion and political ideology of its membership. And lastly, trade unions provide a mechanism where individuals can develop outside their jobs and participate in decision making.

The trade union movement also has a challenge in dealing with a diverse membership to their organizations. Reynaud (1983: 247) argues that the social groups that are brought together under the label of white-collar workers certainly possess specific characteristics which decisively distinguish them from manual workers.

This presents a challenge that could easily lead to conflicts in that the diversity of the needs of such a varied constituency need to be well accommodated. If not, splits and incessant internal squabbling will characterize the labour union movement.

The other challenge that appears evident in Botswana is that the white-collar worker is conscious of his/her chances of becoming part of management

because of their greater promotion chances and because, in the main, they have a better market situation, white collar workers, it is held, are more favourable to individual competition than to the making of collective demands, and it is this that turns them away from trade unionism (Reynaud, 1983: 248).

As such, issues of intra-union democracy are important in ensuring that all members' interests are factored in. This proves a challenge for most unions as the white-collar workers are at times less likely to engage in industrial action in the form of strikes while the blue-collar workers are often more likely to engage in industrial action. Also, the conditions of their services often vary, with the white collar worker's conditions and benefits a little more favourable than those of blue collar workers.

The preceding conflicts in unionism in Botswana were succinctly captured by Tswaipe (2010) in Mmegi Online of the $10^{\text {th }}$ July, 2010. 
Today a fact that cannot be hidden is that the trade union movement is at war with itself, not with multinationals or the state. Unions are not fighting viciously against unemployment, wage poverty, indecent jobs or the World Bank-sponsored Privatisation Policy.

It is an inside battle, fought with vigour and fuelled by egos and business alliances. Here and there, unions throw this and that public statement for their media friends, about the government or John Kalafatis, but the undercurrent rages on, undeterred. This time it is much uglier than it has ever been as the two major groupings seem to be fighting for survival. In one corner stands the Botswana Federation of Trade Unions or BFTU and its remaining affiliates, and on the other is the emerging rival federation of public service unions, dubbed Botswana Federation of Public Sector Unions (BOFEPUSU) or 'the Big Five'.

Tswaipe (2010) predicts that some union may disappear, or in the other worst case scenario, that both BFTU and BOFEPUSU may collapse.

\section{Threats posed by trade unions}

1. Trade unions pose a threat to any country because they represent the collective voices of the employees nationwide. However, after 45 years of independence in 2011, trade unions are still weak in Botswana and this is now compounded by the infightings that have been going on since 2007. In September 2010, government responded to the collective voice of unions and as a result a major strike by five major unions which included: the Botswana Land Boards and Local Authorities and health workers Union (BLLAHWU), the National Amalgamated Local Central Government and Parastatal Workers Union (NALCGPWU), the Botswana Teachers Union (BTU), the Botswana Secondary Teachers Union (BOSETU) and the Botswana Public employees Union (BOPEU) was averted. These unions are affiliates of the Botswana Federation of Public Sector Unions (BOFEPUSO). The unions were demanding that the 22 days working month agreed and signed to by the employer should be paid effective from May 2010. Government acted fast to stop the strike by agreeing that they will pay public servants effective from May 2010 arrears amounting to more than P6 billion (http://allafrica.com/stories/printable/201106130984.html).

2. Public servants in Botswana are not well conversant with the labour laws of the country including those who are leading ministries such as Permanent Secretaries, their Deputies and Director. More often than not, they find themselves having gone against some of the laws that govern industrial relations in the country, and unions have been able to embarrass them by taking them to the Industrial Court to have employees either reinstated or paid for unfair dismissals. This therefore, indicates that a lot of training is needed for the government employees and also for the unions.

3. Government has been stalling the introduction of the Bargaining council as provided for in the 2008 Public Service Act. The major problem has been its constitution as the Directorate of Public Service Management (DPSM) tried to somersault by derecognizing some unions which according to them did not reach the 33\% threshold. DPSM seem to be facing a mammoth task that they did not prepare for and as a result unions are becoming a big threat 
to its decision making processes.

4. Botswana has ratified International Labour Organisation conventions that included the right to strike. As a result of that, Botswana cannot afford to ignore employee demands as the ultimate price will be a strike by employees which could cripple the economy that has been ravaged by recession since 2007 to the year 2010 .

\section{State - labour relations in Botswana}

Several authors (Tsie, 1996; Mogalakwe M. \& Siphambe, 2001; Siphambe \& Thokweng-Bakwena, 2001) have attested to the fact that the labor movement in Botswana has been historically weak, mainly due to government's setting of wages. Tsie (1996) identified the following as some of the reasons for the weakness of the labor movement in Botswana. First, the low level of industrialization that Botswana inherited from colonial rule at independence. Botswana was used as a source of unskilled and cheap labor for the South African mines. Second, the low levels of wage labor in the country until the 1980s. Third, the labor movement in Botswana has always been plagued by poor organization and lack of effective leadership. Last, the level of unionization has generally been low due to the fact that the state fixed the minimum wages. This was supposed to change after the introduction of the Incomes Policy of 1991 which stipulated that wages were to be determined by market forces. The situation has not changed as even in 2009 the website of the Department of Labor and home Affairs still listed the minimum wages in different sector of the economy. The subordinate position of unions has not improved as government continues to set minimum wages mainly due the fact that workers concentrate on immediate bread and butter issues and the threat of unemployment. Section 132 of the Employment Act (Employment Act, 2003) gives the Minister the power to set up a Board that will investigate wages in different sector of employment and recommend to him/her what the minimum wage should be. The Minister is not obliged to take their recommendations.

Regardless of the inadequacies identified above, government plays an important role in industrial relations in Botswana. Government provides legal framework for industrial relations and settling trade/industrial disputes. Government also provides legal protection for employees that are stipulated in the Employment Act of 1963 (Amended in 2002) following the 1997 ratification of ILO conventions. The conventions lay the conditions of contract of employment, termination, dismissals, employment of the young and disadvantaged, determination of minimum wages, and employee welfare matters. Some of the conventions ratified by Botswana are shown in Table 1 most of which are partially implemented (Federick Ebert Foundation, 2008, pp. 8-9). 
Table 1 Ratified ILO conventions by government of Botswana

\begin{tabular}{|c|c|c|}
\hline Convention & When Ratified & Provision \\
\hline 1.Weekly rest C014 (1921) & 1988 & $\begin{array}{l}\text { Provides for a day's rest of a working week } \\
\text { of } 7 \text { days }\end{array}$ \\
\hline $\begin{array}{l}\text { 2. Equality of treatment } \\
\text { (Compensation of Injuries at work) } \\
\text { C19 (1949) }\end{array}$ & 1988 & $\begin{array}{l}\text { Equal treatment of workers in cases of } \\
\text { compensation for occupational injuries and } \\
\text { diseases }\end{array}$ \\
\hline 3. Forced labour C029 (1930) & 1997 & Prohibits use of forced labour in all forms \\
\hline 4. Protection of wages C95 (1949) & 1997 & $\begin{array}{l}\text { Restricts deduction from salaries /wages } \\
\text { without workers consent }\end{array}$ \\
\hline 5. Equal remuneration C100 (1951) & 1997 & Prohibits wages discriminations of any kind \\
\hline $\begin{array}{l}\text { 6. Freedom of association and } \\
\text { protection of the right to organize } \\
\text { C087 (1948) }\end{array}$ & 1997 & $\begin{array}{l}\text { Safeguards both workers and employers of } \\
\text { their right to form organisations of choice for } \\
\text { furthering and defending their interest. }\end{array}$ \\
\hline $\begin{array}{l}\text { 7. Right to organize and collective } \\
\text { bargaining C098 (1949) }\end{array}$ & 1997 & $\begin{array}{l}\text { Protects workers in exercising their right to } \\
\text { organize, prevent State interference in } \\
\text { workers' and employers' organisation in } \\
\text { promoting voluntary collective bargaining. }\end{array}$ \\
\hline $\begin{array}{l}\text { 8. Abolition of forced labour C105 } \\
\text { (1957) }\end{array}$ & 1997 & $\begin{array}{l}\text { It advocates for complete abolition of any } \\
\text { kind of forced labour. }\end{array}$ \\
\hline $\begin{array}{l}\text { 9. Discrimination (Employment and } \\
\text { Occupation) C111 (1958) }\end{array}$ & 1997 & $\begin{array}{l}\text { Prohibits discrimination in employment } \\
\text { practices and occupation. }\end{array}$ \\
\hline $\begin{array}{l}\text { 10. Minimum age convention C138 } \\
\text { (1973) }\end{array}$ & 1997 & $\begin{array}{l}\text { Sets minimum age of employees to be } \\
\text { employed in order to prohibit child labour. }\end{array}$ \\
\hline $\begin{array}{l}\text { 11. Tripartite consultation C } 144 \\
\text { (1976) }\end{array}$ & 1997 & $\begin{array}{l}\text { Promotes social dialogue or consultation } \\
\text { between government, workers and } \\
\text { employers at international level on all } \\
\text { international labour standards. }\end{array}$ \\
\hline $\begin{array}{l}\text { 12. Labour relations (Public } \\
\text { Service) C151 (1978) }\end{array}$ & 1997 & $\begin{array}{l}\text { Guarantees the right of workers in the public } \\
\text { sector to organize freely. }\end{array}$ \\
\hline $\begin{array}{l}\text { 13. Protection of workers' claims } \\
\text { (Employer's Insolvency) C173 } 1992\end{array}$ & 1997 & $\begin{array}{l}\text { Provides for higher prioritization of workers } \\
\text { claims against the creditors in the event of } \\
\text { insolvency. Provides for the workers claims } \\
\text { to the extent of three months' pay. }\end{array}$ \\
\hline $\begin{array}{l}\text { 14. Safety and health in mines C176 } \\
\text { (1995) }\end{array}$ & 1997 & $\begin{array}{l}\text { Government to periodically consult with } \\
\text { employer and workers representative on } \\
\text { safety and health issues in mines in order to } \\
\text { avoid fatalities, injuries and ill health of } \\
\text { workers and member s of the public. }\end{array}$ \\
\hline 15. Elimination of worst form of & 2000 & Call for prohibition and elimination of worst \\
\hline
\end{tabular}


form of child labour.

Adapted from: Trade Unions in Botswana Country Report 2008: 8-9

\section{Industrial relations conflict in Botswana from the 1990s to the millennium}

Botswana has been viewed as the Switzerland of Africa due to its peaceful nature in the midst of warring neighbours. In terms of IR, few strikes took place before independence for several reasons; majority of people were not in full employment, employees were mostly intimidated by the employers, the union movement was starting with the help of the newly formed political parties. Historically, Mmusi started the first union in 1948 called the Francistown African Employees Union (FAEU) followed by the Bechuanaland Protectorate Workers Union (BPWU) in 1959 and then the Bechuanaland Trade Union Congress (BTUC) with Klass K. Motshidisi as its first Secretary General in 1962. This pioneer paved the way for industrial relations in Botswana as it exists in its current form (Mogalakwe, 1997).

In the last 20 years, Botswana has seen an increase of strikes carried out by different groups in society. These include public servants, private sector unions and parastatals. These have escalated the conflict and the relationships between the different stakeholders with the industrial relations arena. At this juncture, the paper will discuss the different industrial conflicts as they occur in Botswana.

\section{a. Trade union versus government conflict in Botswana}

Government is the largest employers in the country and that leads to conflict between the employer and the unions. Regardless of being the peaceful country that the world has always admired, Botswana in 2011 was literally "up in flames" due to trade union strikes and the resultant damages which included burning tyres on the roads. The teacher unions have been the most effective and have actually transformed the industrial relations in Botswana. The 2002 teachers strike on parallel progression marked one of the major milestones in industrial relations in Botswana. This does not mean there have not been other strikes before. Government has been defiant and blatantly disregarded some of the court order on issues that concerned staff welfare and at times strikes gave government a rude awakening. This section will mainly chronicle the 2011 strike and the conflicts that arose because of it.

In 2008, government adopted and started implementing the "new" Public service Act. This Act increased the number of working days for public servants from 21 to 22 and this created a big problem for government as it looks like that section of the Act was not thoroughly thought through and actually a lot of loop holes have been identified in the 2008 Act and within short period during its implementation some amendment were made. Government had to pay employees the monies some back pays. In implementation of the 2008 Public Service Act some unions were excluded in the formation of the Labour Advisory Board (LAB) and the Public Service Bargaining Council (PSBC) as their registration was questioned and derecognised. The exclusion caused further rift between government and unions (Ontebetse, 2011; Makgapha,2011a). The proposed model below shows the relationships between 
government and unions.

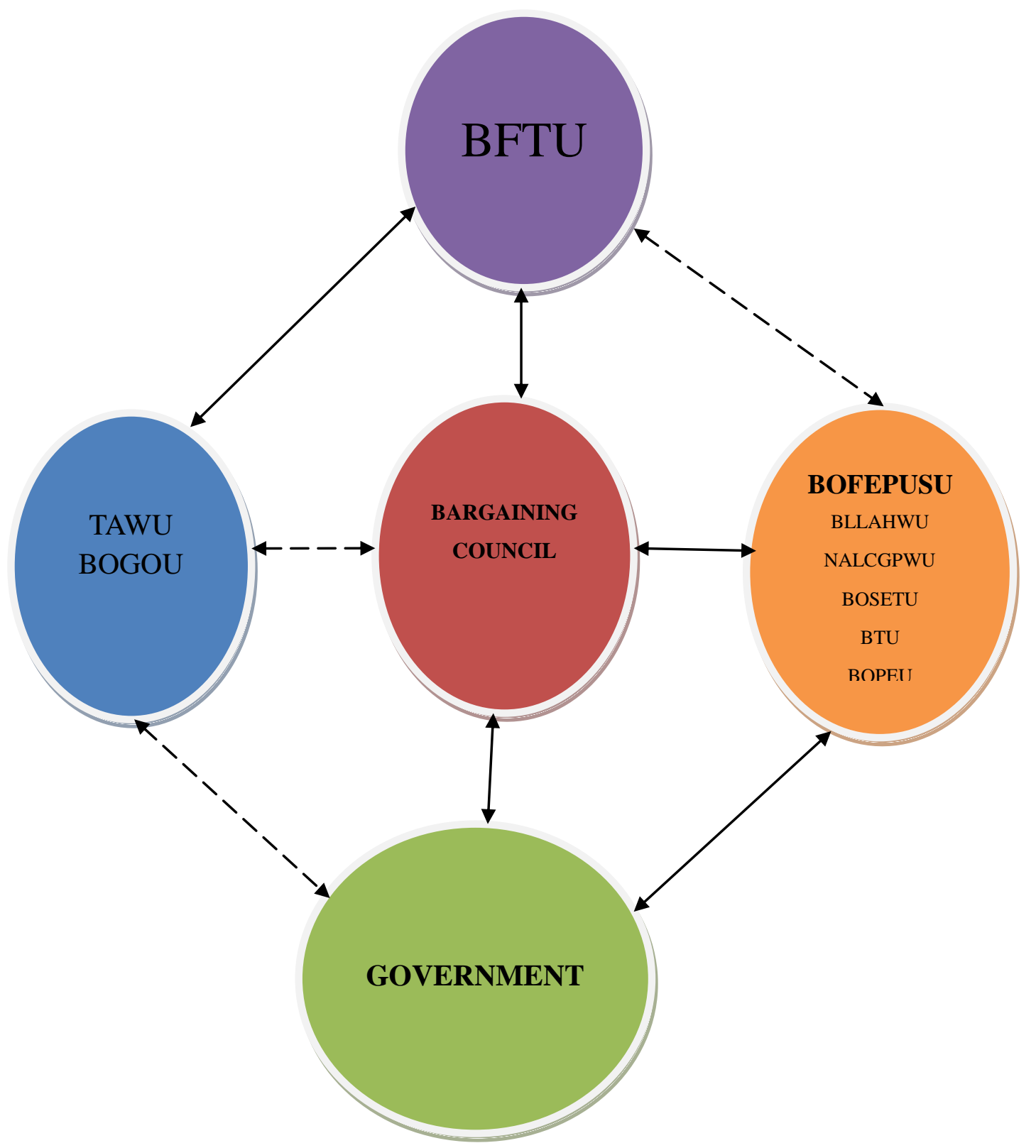

Figure 1 Relationships between trade unions, bargaining Council and government

The 2011 strike brought many conflicts and controversies in Industrial relations in Botswana. Firstly, at the onset of the strike, strike rules agreement was signed by the Directorate of Public Service Management (DPSM) representing government and five of the recognised Unions affiliated to Botswana Federation of Public Sector Unions (BOFEPUSU) (Directorate of Public Service Management, 2011) . The agreement set out members who were excluded from participating in the strike, and the non-essential services that should form 
part of the skeletal staff to man the offices during strike and the provision on minimum service for essential service. Though the law clearly stipulates that essential services are not supposed to be part of the strike, this agreement allowed them to be part of the strike and as expected, this caused conflict as the strike progressed.

The other controversy emerged when government employed William Patrick Vergeer as the Judge of the Industrial Court (IC) regardless of the fact that he had represented DPSM in their case against unions in May 2011. Government continued in its bad faith dealing with unions when they took a decision to stop assisting unions with loan repayments that were deducted from employees' salaries (gabzfmnews, 2011). Government also withdrew office accommodation and transport for unions that had that privilege. These decisions were taken as sort of a vendetta by government against unions.

Some of the instances where government acted in bad faith were the announcement of the 3\% salary increase in Mahalapye by the Head of State before the agreement was signed and while negotiations were still on-going. Unions lead by BOFEPUSU were adamant that the negotiations were still continuing. Finally, it was agreed that the $3 \%$ increase be paid in October but backdated to September (Rantsimako, 2011). Analytically, the 3\% awarded to public servants, it was argued by unions did not add much value as it only managed to move employees to a different tax bracket and some time left worker worse off. Unions had a formula of how they wanted the increases to be administered but government refused and gave everyone across the board that percentage (Rantsimako, 2011).

The protracted nature of the strike brought about its own problems. Initially it was believed the strike will take ten day from April 18 to 29 as per the strike rules agreement. Eventually the strike took 8 weeks from mid-April to mid-June 2011. Government negotiators were powerless and they could not move from their original position of 5\% but the move backward to $3 \%$ was unfair. Most of the union demands and request were not headed by government. For example, unions requested that dismissed employees be reinstated, abolition of the no work no pay agreement and the utilisation of the pyramid method of allocating the $3 \%$ were not acceded to by government until intervention by churches, politicians and other pressure groups within the society (Rantsimako, 2011). The deployment of heavy security (armed police, paramilitary Special Support group and the helicopter) during the strike was intimidating for the strikers and also ended with some striking employees injured.

\section{b. Government unfair tactics during the strike}

Making of pronouncements in the Kgotla (traditional court) meetings while negotiations were still on-going which handicapped the government negotiators. Government spies in the form of CIDs were sent to gatherings (Botswana strike suspended as state deploys heavy security, 2011; Baaitse, 2011). The involvement of the ruling party politicians in the strike was not welcomed by unions even though their motive was to show solidarity with the employees. Some BOFEPUSU officials were detained for "uttering political statements". The sudden amendment of the Trade Disputes Act (2003) to incorporate other cadres like teaching services, diamond sorting, cutting and selling services, and veterinary services using 
Statutory Instrument No 49 of 2011 which was challenged and annulled (Ramsay, 2011) but later reinstated as the Minister followed the right procedures (Makgapha, 2011b).The unions successfully challenged the legitimacy of the Minister to amend the Trade disputes Act and won the case in August 2012 (Morewagae, 2012).

\section{Recommendations}

In view of the above discussions, the following recommendations are made which are hoped to help both unions and management.

1. Government should recognise that they have agreed to negotiate salaries with trade unions when they entered into labour agreements with them. Therefore, she should be able to shed its big brother mentality when involved in negotiations with all unions to avoid breaking the trust between her and the unions to avoid either party from withdrawing from the relationship.

2. Government must speed up the creation and the functioning of the Bargaining Council and ensure that all unions that are supposed to be represented are not left out. A holistic view as opposed to an adversarial way should be utilised.

3. Intimidation of striking employees should be avoided. Government during the 2011 strike was heavy handed in the deployment of the state machinery during the strike.

4. It is imperative to have social dialogue between employer and unions.

5. Trade unions should cooperate when embarking on a national strike (all federations should be involved).

6. Government negotiators should be empowered to take on that role. There should be no interference from the state.

\section{Conclusion}

Conflicts have always been there as long as mankind existed and therefore, conflict is inherently part of any trade union movement in any country. This paper examined conflict that characterised the Botswana Industrial Relations land scape from the 1990s to the new millennium. Botswana has for a long time been seen as the most peaceful country in Southern Africa. Conflict has traditionally been avoided but with the advent of work and infusion of Western values and principles, the value system of Botswana (peaceful coexistence, consultation and participation in decision making processes) of the country changed dramatically. Batswana have always believed that conflicts are better resolved through diplomatic negotiations. In the period under review, there have been strikes that were seen as illegal/ unprotected according to the statutes. The 2008 Public Service Act legalised strikes as long as the striking employees are granted permission by the Labour Commissioner after the mediation fails and the police. The April 2011 strike has so far been the "mother of all trikes" and it raised inadequacies on the part of both government and trade unions that 
need to be addressed.

\section{References}

(2011). Botswana: Civil Servants suspend strike. Retrieved 10 10, 2011, from www.africareview.com: http://www.africareview.com/News/-/979180/1178528/-hnbplvz/-/.

Baaitse, F. (2011). I spy with my little eye. Gaborone, Botswana. Retrieved $17^{\text {th }}$ September, 2011, from http://www.thevoicebw.com/2011/05/20/i-spy -with-my-little-eye/.

Directorate of Public Service Management . (2011). Strike rules Agreement between Directorate of Public Service Management representing government as the employer and five of the recognised unions affiliated to BOFEPUSU (BOPEU, BLLAHWU, BTU, BOSETU and NALCGPWU). Gaborone.

Dlamini, A. (2002). Botswana unions find their voice. SA Labour Bulletin , 26 (1), 20-21.

Dzimbiri, L. B. (2006). Political stability and human rights for organised workers. International Journal of Women, Sciaol Justice and Human Rights , 1 (2), 237-251.

Employment Act. (2003). Gaborone, Botswana: Government of Botswana.

Federick Ebert Foundation. (2008). Trade Unions in Botswana Country Report . Gaborone, Botswana.

Frederick Ebert Stiftung . (2006). Trade unions in Botswana. Gaborone: Friedrich Ebert Stiftung.

Gabzfmnews. (2011). BOFEPUSU seeks court interdict against government. Gaborone. $\begin{array}{llll}\text { Retrieved } & 20 & 10, & 2011 \text {, }\end{array}$ fromhttp://gabzfmnews.wordpress.com/2011/10/05/bofepusu-seeks-court...

Government of Botswana (2003). Employment Act Chapter 47:03. Gaborone, Botswana

Government of Botswana (2008). Public Service Act. Gaborone, Botswana.

Government of Botswana (n.d.) Trade Unions and Employers Organisation Act (TUEA) Chapter 48:01 Gaborone, Botswana.

Government of Botswana (2004) Trade Disputes Act No 15 of 2004. Gaborone, Botswana.

Government of Botswana (n.d.). Workmen's Compensation Act Chapter 47:03. Gaborone, Botswana.

Holley, W. H. (2009). The labour relations process. Mason, USA: South-Western CENGAGE Learning. 
Makgapha, S. (2011a). Public Service Bargaining Council registered. Gaborone, Botswana. Retrieved 28 July, 2012, from http://www.gazette.com

Makgapha, S. (2011b). Did Siele mislead Parliament? Gaborone, Boswana. Retrieved 28 July , 2012, from http://www.gazette.com

Makgapha, S. (2011c). Government to pay 3\% in October. Gaborone, Botswana. Retrieved 28 July , 2012, from http://www.gazette.com

Mogalakwe, M. \& Siphambe, H. K. (2001). Economic performance and labour markets in Botswana. In K. Matlosa, Labour Markets, migration and development in in Southern Africa. Harare: Sarpes Books.

Mogalakwe, M. (1997). Ther State and Organised labour in Botswana. Aldershot: Ashgate.

Morewagae, I. (2012, August 10). Teachers win. Retrieved August 15, 2012, from http://www.mmegi.bw/index.php?sid=1\&aid=418\&dir=2012/August/Friday10

Ontebetse, K. (2011). Unions drag Labour Commissioner to court. Gazette Newpaper Botswana. Gaborone, Botswana. Retrieved Janaury 15, 2012, from http://www.gazettebw.com/index.php?view=article\&catid=18:head...

Ramsay, J. (2011). Government disappointed by annulment of Statutory Instrumenty on Essential services. Gaborone. Republic of Botswana- Office of the President.

Rantsimako, S. (2011). BOFEPUSU to petition government. Gaborone, Botswana. Retrieved 28 July , 2012, from http://www.gazette.com.

Makgapha, S. (2011). Government to pay 3\% in October. Gaborone, Botswana. Retrieved 28 July , 2012, from http://www.gazette.com.

Reynaud, J. (1983). White collar workers and their attitudes to trade unions: An international view. In R. \&. Hyman, The new working class? white collar workrs and their organisations: Areader. London: Macmillan Press.

Siphambe, H. \& Thokweng-Bakwena, M. (2001). The wage gap between men and women in Botswan's formal labour market. Journal of African Economies , 10 (2), 127-142.

Tharenou, P., Donohue, R. \& Cooper, B. (2007). Management Research Methods. Cambridge University Press: Port Melbourne, Australia.

Tregena, F. (2005). Retrieved Febraury 10, 2012, from http://www.policyinnovations.org/ideas/policy_library/data/01387/_res/id=sa_File1/Tregenna _Botswana.pdf

Tsie, B. (1996). The political context of the Botswana's development performance. Journal of Southern African Studies , 22 (4), 599-616. 
Tswaipe, E. B. (2010). Instability in Botswana's - an insiders view. Retrieved February 25, 2012, from http://www.mmegi.bw/index.php?sid=10\&aid=2929\&dir=2010/july/Tuesday6.

Quinlain, C. (2011) Business research methods. South-Western Cengate EMEA: Hampshire, United Kingdom

Zikmund, W. G., Babin, B. J., Carr, J. C. \& Griffin, M. (2013). Business Research Methods. South-Western Cengate Learning: Canada 